\title{
Blackstone's Commentaries and the Privileges or Immunities of United States Citizens: A Modest Tribute to Professor Siegan
}

\author{
ERIC R. CLAEYS*
}

TABLE OF CONTENTS

I. ProfESSOR SiEgAN's SCHOLARShIP ON THE PRIVILEgES OR

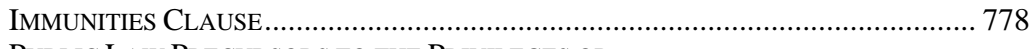

II. PUBlic LAW PRECURSORS to The PRIVILEgES OR

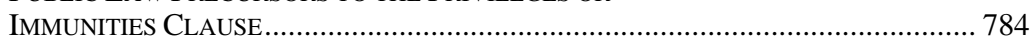

III. BLACKSTONE'S COMMENTARIES ON PRIVILEGES OR IMMUNITIES .............................. 789

IV. PRIVILEGES OR IMMUNITIES: THE AMERICAN TURN .............................................. 793

V. The Original Public Meaning of the Privileges

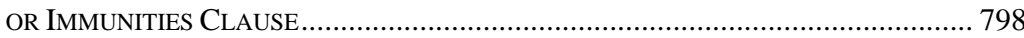

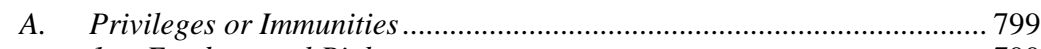

1. Fundamental Rights.................................................................. 799

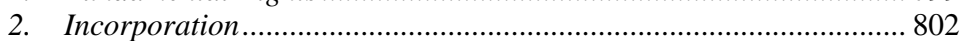

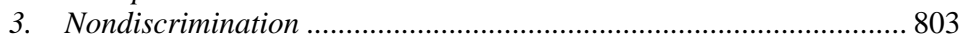

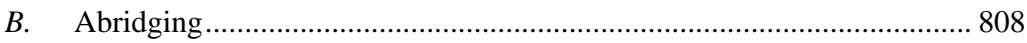

C. Entitled and the Comity Clause .......................................................... 811

* ${ }^{\odot}$ Eric R. Claeys 2008. Associate Professor of Law, George Mason University. Drafts of this essay were presented at the November 2007 conference on Economic Liberties and the Original Meaning of the Constitution at the University of San Diego and at a March 2008 Levy Workshop at the George Mason University School of Law. I am especially grateful for comments and criticisms from Richard Aynes, David Bernstein, Nelson Lund, Jeremy Rabkin, Mike Rappaport, Larry Solum, William Michael Treanor, and Keith Whittington. 


\section{PROFESSOR SiEgAN's SCHOLARSHIP ON THE PRIVILEGES OR IMMUNITIES CLAUSE}

I never met Bernard Siegan, but as I write this essay I am keenly aware that I owe him a significant scholarly debt. Today in the American legal academy, defenders of traditional property rights are a fairly small minority. ${ }^{1}$ We are probably not numerous enough to be influential. But there are enough of us that we can learn from one another, and enjoy the friendly pleasures that come from cooperating in pursuit of commonly shared ideals. Professor Siegan had far fewer friendly colleagues when he wrote most of his important works. He forged ahead anyway. In doing so, he helped clear the intellectual terrain in property and land use that my cohort now takes for granted.

I say all this uncertain of how Professor Siegan's scholarship will be received in another generation. Although Siegan wrote widely on property and land use, he is best remembered for his writings on the topics that guide this Symposium - the relation between property, economic liberty, and the United States Constitution. ${ }^{2}$ Those writings are caught in the same bind as Richard Epstein's writings on the same topics today. Most non-originalists reject Siegan's and Epstein's theories of property and government on the merits. So if either's constitutional work is going to be taken seriously in another generation, it will need to be among constitutional scholars who sympathize with traditional property rights. But many constitutional scholars who fit that description are skeptical of constitutional property rights. $^{3}$ As the proceedings of this memorial conference illustrate, many originalist scholars are skeptical that the Constitution protects in a meaningful way property rights or unenumerated economic fundamental rights. ${ }^{4}$

1. See Eric R. Claeys, Takings: An Appreciative Retrospective, 15 WM. \& MARY Bill RTs. J. 439, 443-44 (2006) (reviewing Richard A. Epstein, TAKINGS: PRIVATE PROPERTY AND THE POWER OF EMINENT DOMAIN (1985)).

2. See, e.g., BERnard H. SiEgAn, ECONOMiC Liberties AND the Constitution (1980) [hereinafter Siegan, Economic Liberties]; Bernard H. Siegan, LAND Use WiTHOUT ZONING (1972).

3. See Claeys, supra note 1 , at 439-41 (diagnosing different sources of academic resistance to Richard Epstein's views regarding constitutional property rights).

4. See, e.g., John Harrison, The Constitution of Economic Liberty, 45 SAN DiEGO L. REV. 709 (2008); William Michael Treanor, Take-ings, 45 SAN DiEGo L. REv. 633 (2008). 
In this essay, I hope to contribute to Professor Siegan's legacy by suggesting some new reasons why originalists ought to take more seriously fundamental rights readings of the Constitution. This essay focuses on a single provision of the Constitution: the Fourteenth Amendment's Privileges or Immunities Clause, which reads, "No State shall make or enforce any law which shall abridge the privileges or immunities of citizens of the United States." 5 This Clause more than any other symbolizes the divisions between originalists about the status of unenumerated fundamental rights. In Saenz v. Roe, ${ }^{6}$ Justice Thomas wrote a separate opinion to signal that he read the Privileges or Immunities Clause of the Fourteenth Amendment to protect certain general natural rights relating to citizenship. ${ }^{7}$ I will refer to Thomas's general approach as the "fundamental rights" species of originalism. Professor Siegan propounded a fundamental rights reading of the Privileges or Immunities Clause, ${ }^{8}$ and Randy Barnett ${ }^{9}$ and Richard Epstein have endorsed this interpretation more recently. ${ }^{10}$

The main alternative to the fundamental rights approach is a formalist approach. According to this approach, most, if not all, of the provisions of the Constitution implement determinate, rule-like provisions, which need not be fleshed out with reference to general moral principles of natural rights or anything else. Although Justice Scalia did not write his own opinion in Saenz, he did not join Justice Thomas's opinion. ${ }^{11}$ It is reasonable to suspect that Scalia refrained from joining Thomas's opinion because he harbors formalist doubts about a fundamental rights interpretation of the Privileges or Immunities Clause. ${ }^{12}$ In originalist scholarship, there

5. U.S. Const. amend. XIV, § 1.

6. Saenz v. Roe, 526 U.S. 489 (1999).

7. See id. at 524 (Thomas, J., dissenting)

8. See BERnARD H. Siegan, The SuPREME Court's Constitution: An INQUiRy INTO JUDICIAL REVIEW AND ITS IMPACT ON SOCIETY 64-71 (1987).

9. See Randy E. Barnett, Restoring the Lost Constitution: The Presumption OF LIBERTY 194-203 (2004).

10. Richard A. Epstein, Further Thoughts on the Privileges or Immunities Clause of the Fourteenth Amendment, 1 N.Y.U. J.L. \& LIBERTY 1096, 1098-99 (2005); Richard A. Epstein, Of Citizens and Persons: Reconstructing the Privileges or Immunities Clause of the Fourteenth Amendment, 1 N.Y.U. J.L. \& LIBERTY 334, 340-51 (2005) [hereinafter Epstein, Of Citizens and Persons].

11. See Saenz, 526 U.S. at 491, 521.

12. See also Troxel v. Granville, 530 U.S. 57, 91 (2000) (Scalia, J., dissenting) (arguing that parents' right to raise their children is "among the 'unalienable Rights" declared in the Declaration of Independence and the Ninth Amendment, but not a judicially enforceable right). 
are several different formalist renditions of the Clause. The hardline rendition is Robert Bork's: The terms privileges and immunities are so open ended that they are really just "ink blots," which can be read to encompass any civil right the interpreter wants to protect. ${ }^{13}$ Another formalist position is the "nondiscrimination" approach. As David Currie ${ }^{14}$ and John Harrison explain, this view asserts that privileges and immunities refer to state laws specifying the content of subject areas covered by traditional fundamental rights. States have considerable latitude regarding how to specify the content of those subject areas. But once they have chosen the privileges and immunities that they will provide, states must provide the legal rights on justifiably equal terms to all citizens. ${ }^{15}$

Although a tribute essay cannot settle the debates over the Privileges or Immunities Clause or Professor Siegan's scholarship, it can at least suggest that Siegan was righter than most originalists now appreciate. This essay does so by focusing on three key terms in the Privileges or Immunities Clause: privileges, immunities, and abridging. ${ }^{16}$ Taken at face value, these terms have no obvious connection to natural law or rights principles. They seem therefore to confirm formalist readings of the Fourteenth Amendment.

Yet appearances can be deceiving. It is important to understand the deception here, because it highlights a dangerous tendency in researching the original meaning of the Constitution and especially the Fourteenth Amendment. Many prominent studies of the Fourteenth Amendment focus on materials contemporaneous with the Amendment's drafting and ratification. Professor Siegan himself exemplifies this tendency; his studies of the Privileges or Immunities Clause are primarily on "what motivated the 128 representatives and 33 senators who favored the joint resolution proposing the [F]ourteenth [A]mendment."17 The debates in the Thirty-Ninth Congress are definitely the place to start, but they are not the only place to look. Privileges and immunities had a long pedigree in English and American public law going back at least as early

13. Robert H. Bork, The Tempting of America: The Political Seduction of THE LAW 166 (1990).

14. See David P. Currie, The Constitution in the Supreme Court: The First HuNDRED YEARS, 1789-1888, at 239 n.12, 342-51 (1985).

15. See John Harrison, Reconstructing the Privileges or Immunities Clause, 101 YALE L.J. 1385, 1410-33, 1451-66 (1992).

16. See U.S. ConsT. amend. XIV, § 2 ("No State shall make or enforce any law which shall abridge the privileges or immunities of citizens of the United States ....").

17. SIEgAn, supra note 8, at 47. One important exception is EARL M. Maltz, The FouRTEENTH AMENDMENT AND THE LAW OF THE CONSTITUTION (2003). Maltz pays closer attention than most to the antebellum legal concepts that shaped the debates over the Fourteenth Amendment. See id. at 3-51. Even so, Maltz's discussions of antebellum law needs to be complemented by close analysis of the moral and political theory that informed the law. 
as the seventeenth century. The terms have a long association in AngloAmerican law, history, and political theory with general principles of citizenship and the social compact. Understood in the context of the rights of citizen-parties to the social compact, the privileges and immunities referenced in the Fourteenth Amendment declare fundamental substantive rights grounded in natural law and rights theory. The term abridging confirms the same result. In Anglo-American moral theory, abridging usually refers to "diminishing the substance of a pre-political moral right more than necessary for its proper regulation."

I invoke the symposium presenter's privilege in this essay and speculate to a large extent against the grain of previous scholarship. Since most scholarship has been done on the legislative and ratification debates about the Amendment without sufficient regard for antebellum moral and political context, I focus here on elucidating that context even if doing so abstracts from the sources most immediate to the Fourteenth Amendment's ratification. This essay surveys colonial charters and relevant provisions of the Articles of Confederation-but most of all Sir William Blackstone's Commentaries on the Laws of England. ${ }^{18}$ Blackstone's discussion explains how the terms privileges and immunities are intertwined with natural law and natural rights principles. In Blackstone's conception, all governments are obligated by natural law to secure the natural rights of their subjects, but the English polity of his day succeeded more than most at doing so. Precisely speaking, privileges and immunities refer not to natural rights, but rather to the rights the English polity established in positive law to secure natural rights—specifically natural rights relating to life, liberty, and property. If Blackstone's usages are representative, when privileges and immunities are used as terms of art in connection with constitutionalism and citizenship, they refer to positive laws that secure natural rights, especially rights that connect directly to the moral rights of life, liberty, and property. In addition, privileges and immunities refer to rights-securing legal protections that may properly be reserved for the special enjoyment of citizens who pledge their allegiance to the republican political community.

Of course, there are good reasons why Blackstone's Commentaries might not be representative of the Fourteenth Amendment. The Commentaries were written a century before the Fourteenth Amendment

18. William Blackstone, Commentaries on the LAWS OF ENGLAND (W.S. Hein \& Co. 1992) (1766). 
was ratified. The Commentaries were influential in American legal and political practice before and shortly after the American Revolution, but by the Civil War, they had been supplanted to some extent by homegrown American legal treatises. It is also probable that American usages of privileges and immunities evolved significantly from 1766 to the postCivil War period. The United States consisted not, as Blackstone's England did, of one monarchical government, but of a collection of republican governments. Furthermore, the United States' experience with slavery over the first half of the nineteenth century must have colored perceptions of privileges and immunities.

Nevertheless, in this essay I hope to suggest that Blackstone's Commentaries are an indispensable aid in deciphering what privileges and immunities mean as terms of art in the Fourteenth Amendment. Leading scholarship on the Fourteenth Amendment assumes that "most American lawyers began their legal education with Blackstone and the common law."19 Offhand statements like these make it all the more surprising that scholarship has noted Blackstone's treatment of privileges and immunities in passing without giving the careful interpretation it deserves. $^{20}$ Even assuming American jurists and lawyers did not read Blackstone himself, his usages of privileges and immunities-properly adjusted for changing American history and political conditions-may capture the background assumptions that those jurists and lawyers assumed to be true when they used the terms.

Blackstone's discussion is valuable for two main reasons. First, Blackstone makes sense of and lends credibility to the discussion of privileges and immunities in Corfield v. Coryell, an 1823 circuit court decision widely regarded as the most important legal source relevant to the original meaning of the Privileges or Immunities Clause. ${ }^{21}$ Second, and more generally, Blackstone's discussion suggests that the fundamentalrights interpretation of the Privileges or Immunities Clause fits antebellum law and political theory more closely than the nondiscrimination view and more closely than is commonly thought.

Before proceeding, let me make a few disclaimers. First, this essay to a large extent abstracts away from questions about what kinds of topics are covered under privileges or immunities. As I will suggest through quotations and case examples, it was widely assumed that privileges and immunities covered positive law rights securing property and the right to practice a commercial trade. This essay abstracts away from questions

19. AKhil Reed Amar, The Bill of Rights: Creation ANd ReCONSTRUCtion 169 (1998).

20. See, e.g., id.

21. Corfield v. Coryell, 6 F. Cas. 546 (C.C.E.D. Pa. 1823) (No. 3230). 
about whether religious freedom, associational freedom, the right of selfdefense, the right to a jury trial, or other similar rights could count as privileges or immunities. Separately, even for topics like property and the right to practice a commercial trade, I avoid questions about whether privileges and immunities could refer to all positive laws securing those natural rights, or to some subset of those rights.

Second, this essay is mostly positive and only modestly normative. For the most part, it aims to explain assumptions about the relationship between natural rights and positive law that are crucial in providing context for privileges and immunities. The essay is normative only to the extent that it makes these assumptions plausible enough for contemporary readers to understand and appreciate. Strong arguments may be made whether the Fourteenth Amendment is "unworkable or incoherent.",22 This essay abstracts away from those arguments.

Third, this essay tries as much as possible to refrain from taking sides in debates about originalist methodology. Readers interested in the finer points of textualism, original understanding, and intentionalism can refer to the footnotes for helpful introductions to the literature. ${ }^{23}$ Blackstone's Commentaries and the other sources canvassed here may be more relevant to one method of inquiry than another. ${ }^{24}$ But they are surely relevant to any originalist interpretation of the Privileges or Immunities Clause. Whatever the species of originalism, the Commentaries are a legal version of a Rosetta Stone.

Fourth, to focus on what the Privileges or Immunities Clause means, this essay abstracts away from questions about which branch or branches of the federal government are best positioned to construe the

22. Roderick Hills, Jr., Back to the Future: How the Bill of Rights Might Be About Structure After All, 93 Nw. U. L. REV. 977, 992-1002 (1999) (reviewing AMAR, supra note 19).

23. See, e.g., John Harrison, Forms of Originalism and the Study of History, 26 HARV. J.L. \& PUB. POL'Y 83 (2003) (explaining the differences between Originalism Mark I, which emphasizes the public political meaning of laws, with Originalism Mark II, which demands a study of history in the interpretation of authoritative text); Vasan Kesavan \& Michael Stokes Paulsen, The Interpretive Force of the Constitution's Secret Drafting History, 91 GEO. L.J. 1113, 1134-48 (2003) (examining the debates among originalists regarding whether to view texts according to the subjective intent of the original drafters, or according to an objective understanding); Gary Lawson, Conservative or Constitutionalist?, 1 GEO. J.L. \& PUB. POL’y 81, 81-82 (2002) (explaining the difference between theories of judicial behavior and theories of interpretation).

24. They are probably more relevant to textualists than to intentionalists or original understanding interpreters. 
Clause and carry its prescriptions into effect in practice. Most scholarship that endorses the fundamental rights interpretation of the Privileges or Immunities Clause typically also endorses vigorous judicial enforcement of the Clause. ${ }^{25}$ While this essay makes the fundamental rights interpretation more respectable, it makes no claims for or against strong judicial review. Obviously, to the extent current law allows for and the Constitution requires strong judicial review, this essay encourages more vigorous federal judicial protection of citizens' property and commercial rights. But it could be that Section Five of the Fourteenth Amendment ${ }^{26}$ makes the Amendment a more Congress-centered amendment than it is assumed to be now. Separately, this essay explains privileges and immunities so as to make them seem more determinate, and also highlights important gray areas in the terms. Different theories of judicial review may disagree about whether such gray areas are more appropriately left to "construction" by the political branches or to legal interpretation by courts. ${ }^{27}$ Those debates exceed the scope of this essay.

In short, this essay focuses on proper interpretation of the Privileges or Immunities Clause separate from the Clause's construction. It leaves significant detail work to complete a sound originalist interpretation of the Clause. Yet if Blackstone's Commentaries and other foundational American public law sources are reliable guides, Professor Siegan had sounder instincts about the original meaning of "privileges or immunities of citizens of the United States” than most originalists now appreciate.

\section{PUblic LaW PRECURSORS TO THE PRIVILEGES OR IMMUNITIES CLAUSE}

Even though considerable scholarship has been written about the terms privileges and immunities as used in the Fourteenth Amendment, we are still a long way from any sort of consensus about what these terms mean. Among many other reasons, interpreters must shed several misconceptions before considering the Fourteenth Amendment in context. The most common misconception is to assume that privileges and immunities are entirely creations of positive law. In everyday conversation and modern legal usage, privileges and immunities often refer to

25. See, e.g., BARnEtT, supra note 9, at 131-52; SiEgAn, ECONOMIC LiBertiEs, supra note 2, at 83-108.

26. See U.S. Const. amend. XIV, § 5 ("The Congress shall have power to enforce, by appropriate legislation, the provisions of this article.”). The terms legislation and appropriate may impose a nondelegation doctrine on legislation under Section Five comparable to the nondelegation doctrine required under Article I of the Constitution.

27. KeIth E. WhitTington, Constitutional InTERPREtation: TeXtual Meaning, ORIGINAL INTENT, AND JUDICIAL REVIEW 5-15 (1999). 
entitlements created as a special favor or perquisite to the recipient. (I used privilege in this sense in Part I, when I appealed to the "symposium presenter's privilege.”) Privileges and immunities were used in antebellum law in this sense. For example, in nineteenth century constitutional law, a privilege often referred to an exclusive, chartered monopoly granted by the sovereign. ${ }^{28}$ At the other extreme, privileges and immunities may be understood as synonyms for moral terms like liberty, right, or freedom. ${ }^{29}$

Although this essay does not claim to settle such issues conclusively, it can suggest why a middle ground is more plausible than either of these two alternatives. Sound originalist analysis must be open to the possibility that a term may be used differently in different contexts. A purchase and sale agreement, for example, uses the term purchase differently from the words of purchase in a conveyance. So too with privileges and immunities. There are plausible reasons for suspecting that, as of the Civil War, privileges and immunities had meanings specific to contexts associated with republican citizenship that they did not have in other contexts. In many contexts before the Civil War, privileges and immunities associated with citizenship referred to civil laws established to secure important moral rights considered crucial to the political community. In these contexts, privileges and immunities relate to both natural and civil law. They are creations of positive law, but with the purpose of carrying the natural law into effect.

This Part briefly surveys some of the most prominent public law usages of privileges and immunities in contexts associated with citizenship. Although these usages have been duly noted and cited in judicial opinions $^{30}$ and scholarship, ${ }^{31}$ these works have not sufficiently appreciated the precise character of the privileges and immunities so referenced.

28. See MALTZ, supra note 17 , at 28-29.

29. See, e.g., Saenz v. Roe, 526 U.S. 489, 524 (1999) (Thomas, J., dissenting) (concluding that privileges and immunities refer to fundamental moral rights); AMAR, supra note 19, at 167-69 (concluding that privileges, immunities, rights, and freedom are interchangeable terms); Harrison, supra note 15, at 1416 (same).

30. See, e.g., Saenz, 526 U.S. at 523 n.2 (noting references to privileges and immunities in seventeenth century American colonial charters).

31. See, e.g., AMAR, supra note 19, at 167-68 (noting references to privileges and immunities in American treaties regulating the subjection of foreign subjects to U.S. jurisdiction). 
A good place to start is Article IV of the Articles of Confederation:

The better to secure and perpetuate mutual friendship and intercourse among the people of the different states in this union, the free inhabitants of each of these states (paupers, vagabonds, and fugitives from justice, excepted) shall be entitled to all privileges and immunities of free citizens in the several states; and the people of each state shall have free ingress and regress to and from any other state, and shall enjoy therein all the privileges of trade and commerce, subject to the same duties, impositions, and restrictions, as the inhabitants thereof respectively. Provided that such restriction shall not extend so far as to prevent the removal of property imported into any state to any other state of which the owner is an inhabitant; provided also, that no imposition, duties, or restriction, shall be laid by any state on the property of the United States, or either of them. ${ }^{32}$

Even though this Clause is repetitive in some respects, its core meaning is tolerably clear. Before the Revolution, each of the colonies was bound by its own charter and general imperial law to respect the rights of subjects in other English colonies. In his Commentaries on the Constitution of the United States, Justice Joseph Story explained:

[A]lthough the colonies were independent of each other in respect to their domestic concerns, they were not wholly alien to each other. On the contrary, they were fellow subjects, and for many purposes one people. . . . The commercial intercourse of the colonies, ... . was regulated by the general laws of the British [E]mpire; and could not be restrained, or obstructed by colonial legislation. ${ }^{33}$

Article IV picked up where these colonial and English guarantees left off. The Article guaranteed that free inhabitants in one state could enjoy in other states the legal rights that the English government had previously guaranteed them when they were English subjects traveling to sister colonies. Article IV replaced a guarantee enforced by English courts and the English Crown with a half constitutional, half international treaty guarantee, enforceable in state courts.

Important in this economic liberties Symposium, these colonial and confederate rights include rights relating to property and trade. Article IV specifically guarantees "the people of each state"-whoever they are- "all the privileges of trade and commerce," and it also guarantees that state economic regulations "shall not extend so far as to prevent the removal of property imported into any state." ${ }^{34}$ Justice Story assumed that colonial and general British law guaranteed each colonist a right, "as a British subject, [to] inherit[] lands by descent in every other colony”

32. ARTICLES OF CONFEDERATION art. IV, § 1 (U.S. 1781).

33. 1 JOSEPH STORY, COMMENTARIES ON THE CONSTITUTION OF THE UNITED States: With a Preliminary View of the Constitutional History of the Colonies AND STATES, BEFORE THE ADOPTION OF THE CONSTITUTION § 178, at 164 (1833).

34. ARTICLES OF CONFEDERATION art. IV, § 1 (U.S. 1781). 
and to engage in "commercial intercourse" consistent with "the general laws of the British [E]mpire."35 Blackstone's Commentaries confirms as much when it examines the rights of aliens and English born subjects. ${ }^{36}$ Aliens could not acquire real estate-at least not without automatically forfeiting it to the crown-they could only acquire personalty except as a matter of "indulgence"; they could trade and work freely, but only subject to higher duties. ${ }^{37}$ By reverse inference, citizens could acquire realty and personalty as of right, work and trade, and were able to do so subject to lower duties.

Article Four, Section Two, Clause One of the U.S. Constitution (called here "the Comity Clause") does in the Constitution what Article IV does in the Articles of Confederation. The Comity Clause reads: "The Citizens of each State shall be entitled to all Privileges and Immunities of Citizens in the several States." ${ }^{\text {"38 }}$ Although this Clause is more laconic than Article IV of the Articles, here less is more. Article IV of the Articles is somewhat repetitive, and the repetitions create internal inconsistencies. As Federalist No. 42 observed, Article IV secures different rights to "free inhabitants" and "the people of each state," and it holds out the possibility that a free inhabitant of one state, who is not entitled to certain rights of citizenship in that state, may demand "all privileges and immunities of free citizens" in other states. ${ }^{39}$ By contrast, the Comity Clause focuses on a uniform set of peoplecitizens in each state-and a uniform set of rights-privileges and immunities.

For the most part, the Articles and the Comity Clause were not using old terms in new contexts. The term privilege was being used as a term of art for fundamental English rights as early as the beginning of the seventeenth century. Perhaps the most prominent early usage of the term comes in a Protestation adopted by the British Parliament, authored by Sir Edward Coke in 1621, in protest against King Charles I. ${ }^{40}$ In the

35. 1 STORY, supra note 33 , at 164 .

36. 1 BLACKSTONE, supra note 18 , at 354

37. Id. at *360; see also 2 JAMES Kent, COMMENTARIES ON AMERICAN LAW 46-54, 60-61 (Da Capo Press 1971) (1827) (comparing and contrasting the rights and disabilities of aliens and citizens in their powers to acquire and dispose of real estate).

38. U.S. CONST. art. IV, § 2.

39. See, e.g., The Federalist No. 42, at 215, 220 (James Madison).

40. John Rushworth, Historical Collections of Private Passages of State: VOLUME 1: 1618-29 (1721), available at http://www.british-history.ac.uk/report.aspx? compid=70138. 
course of protesting the King's domestic, religious, and foreign policies, Parliament insisted "[t]hat the Liberties, Franchises, Priviledges [sic], and Jurisdictions of Parliament, are the ancient and undoubted Birthright and Inheritance of the Subjects of England . . .."41 Parliament made this claim not to assert any natural rights of English subjects, but rather to assert coequal governance rights in "affairs concerning the King, State and Defence of the Realm, and of the Church of England" and to claim freedom of speech for members of Parliament to discuss these subjects. ${ }^{42}$ Even so, privileges and the other terms of art mentioned make sense as placeholders for substantive rights that Englishmen enjoy by virtue of being Englishmen.

In the same period, privileges and immunities were also being used in American colonial charters. In Virginia's 1606 colonial charter, King James I granted to "all and every the Persons being our Subjects . . . all Liberties, Franchises, and Immunities, within any of our other Dominions, to all Intents and Purposes, as if they had been abiding and born, within this our Realm of England, or any other of our said Dominions." "43 The 1629 Charter of the Colony of New Plymouth guaranteed that "all and every the Subjects of [King James and his successors], which shall [go] to and [inhabit] within [the chartered colony], and every of their Children . . . shall have and enjoy all liberties and Immunities of free and [natural Subjects] within any of the [Dominions] of" the English Crown. ${ }^{44}$ These and similar guarantees to other colonies ${ }^{45}$ supplied the background

41. Id.

42. Id.

43. The First Charter of Virginia-1606, reprinted in 7 THE FEDERAL AND STATE CONSTITUTIONS: COLONIAL CHARTERS, AND OTHER ORGANIC LAWS OF THE STATES, Territories, and Colonies Now or Heretofore Forming the United States of AMERICA 3783, 3788 (Francis Newton Thorpe ed., William S. Hein \& Co., Inc. 1993) (1906) [hereinafter THE FEDERAL AND STATE CONSTITUTIONS].

44. Charter of the Colony of New Plymouth Granted to William Bradford and His Associates-1629, reprinted in 3 THE FEDERAL AND STATE CONSTITUTIONS, supra note 43, at 1841, 1856-57 (archaic usages conformed to modern English).

45. See, e.g., Charter of Carolina-1663, reprinted in 5 The Federal AND State Constitutions, supra note 43, at 2743, 2747 ("liberties, franchises, and priviledges [sic]"); Charter of Maryland-1632, reprinted in 3 THE FEDERAL AND STATE CONSTITUTIONS, supra note 43, at 1669, 1681 ("We will also . . . firmly charge, constitute, ordain, and command . . . that all ... Subjects and Liege-Men of US . . . [shall enjoy] all Privileges, Franchises and Liberties of this our Kingdom of England . . . and the same may use and enjoy in the same manner as our Liege-Men born . . . within our said Kingdom of England, without Impediment, Molestation, Vexation, Impeachment, or Grievance of Us"); Charter of Rhode Island and Providence Plantations-1663, reprinted in 6 THE FEDERAL AND STATE CONSTITUTIONS, supra note 43, at 3211, 3220 ("[T] he subjects . . . shall have and enjoye all libertyes and immunityes of ffree [sic] and naturall [sic] subjects within any the dominions of" the crown "as if they, and every of them, were borne within the realme of England.”). 
that the Founders and Justice Story assumed when they construed Article IV of the Articles of Confederation and the Comity Clause.

Of course, a complete analysis of privileges and immunities would need to determine whether the terms evolved in meaning from 1600 to 1868. The terms certainly did develop in some respects. In particular, before 1776, in the contexts relevant here, privileges and immunities referred to the legal liberties of English subjects - established to specify and give effect to the moral guarantees agreed to as part of the unwritten constitution established between the crown and Parliament on behalf of English subjects everywhere. In the United States after 1776, privileges and immunities referred to more or less the same legal and moral freedoms-but as established by and for the benefit of republican citizens. There might have been other similarly serious developments that account for changes in English government, changes in American government, understandings about the proper bounds of church and state, and other factors. Even accounting for such changes, however, as of 1868, privileges and immunities of citizenship probably referred to a collection of legal rights securing moral rights particularly associated with membership in a free government constituted on Anglo-American political principles.

\section{BLACKSTONE’S COMMENTARIES ON PRIVILEGES OR IMMUNITIES}

The authorities canvassed in the previous Part help focus the issue, but they do not settle it. Those authorities suggest that privileges and immunities of citizenship in an American republic refer to "legal rights established to specify and give effect to moral rights to which members of the political community are entitled according to a generalized AngloAmerican political tradition.” But those legal rights could be construed in one of several different ways - the nondiscrimination or the fundamental rights interpretations. Here is where Blackstone's Commentaries are helpful. The Commentaries lend strong support to the fundamental rights reading.

After defining the nature of law and English law, ${ }^{46}$ the Commentaries begin in earnest by explaining the absolute-or moral, prepolitical, and inalienable-rights of individuals. ${ }^{47}$ After reviewing how Magna Carta and other foundational English laws secure absolute rights, William Blackstone expounds on the social compact more generally:

46. See 1 BlacKSTONE, supra note 18 , at *2-115.

47. See id. at $* 117$. 
Thus much for the declaration of our rights and liberties. The rights themselves thus defined by [Magna Carta and the other discussed] statutes, consist in a number of private immunities; which will appear, from what has been premised, to be indeed no other, than either that residuum of natural liberty, which is not required by the laws of society to be sacrificed to public convenience; or else those civil privileges, which society hath engaged to provide, in lieu of the natural liberties so given up by individuals. These therefore were formerly, either by inheritance or purchase, the rights of all mankind; but, in most other countries of the world being now more or less debased and destroyed, they at present may be said to remain, in a peculiar and emphatical manner, the rights of the people of England. And these may be reduced to three principal or primary articles; the right of personal security, the right of personal liberty; and the right of private property: because as there is no other known method of compulsion, or of abridging man's natural free will, but by an infringement or diminution of one or other of these important rights, the preservation of these, inviolate, may justly be said to include the preservation of our civil immunities in their largest and most extensive sense. ${ }^{48}$

This passage is bound to invite competing interpretations - consider, for example, Blackstone’s slightly conflicting references to "private immunities" and "civil immunities." Nevertheless, Blackstone's exposition is more discursive than most legal documents. Blackstone makes patent several assumptions about privileges and immunities that are only latent in practical documents.

Blackstone presumes that Englishmen enjoy natural rights under natural law. If that were not clear enough from his several references to "natural liberty," it is reinforced by the fact that he speaks of the Magna Carta and other foundational statutes as "declaration[s]" of natural liberty. In principle, these foundational statutes do not give English subjects new rights; they merely "declare" that the subjects have in civil law rights they already enjoy as a matter of natural law. Later, Blackstone stresses that "the principal aim of society is to protect individuals in the enjoyment of those absolute rights, which were vested in them by the immutable laws of nature; but which could not be preserved in peace without that mutual assistance and intercourse, which is gained by the institution of friendly and social communities."49

In addition, these natural rights are the rights popularly associated with Locke-life ("personal security"), liberty, and private property. ${ }^{50}$ Blackstone reinforces this point in the rest of the same chapter. He suggests that life, liberty, and property may "usually [be] summed up in

48. Id. at $* 125$.

49. Id. at $* 120$.

50. See John Locke, Two Treatises of Government § 87, at 323 (Peter Laslett ed., Cambridge Univ. Press 1988) (1698) (justifying political society on the basis of a power that man "hath by Nature . . . to preserve his Property, that is, his Life, Liberty and Estate”). 
one general appellation, and denominated the natural liberty of mankind.”51 This natural liberty is not a right to any guaranteed handouts or specific policies from the government. It is instead a negative liberty, a domain of non-interference. It "consists properly in a power of acting as one thinks fit, without any restraint or control, unless by the law of nature." 52

That said, Blackstone is not totally clear about how moral privileges and immunities acquire legal or customary force under the unwritten English constitution. On one hand, they might have authority in natural reason. The natural rights of personal security, personal liberty, and private property, Blackstone assumes, are "the rights of all mankind." On the other hand, the foundation might be community authority, specifically in the form of the English people's consent to those principles. Blackstone suggests as much when he acknowledges that the natural rights in question are "in a peculiar and emphatical manner, the rights of the people of England" because they have been "more or less debased or destroyed" elsewhere. In this respect, too, Blackstone follows Locke: While political society is judged by how well it secures basic natural rights, it also depends crucially on the consent of the governed. ${ }^{53}$

In any case, in organized political society, English subjects exchange natural rights for positive law rights - on condition that the society pledge to make its common end the preservation and enlargement of natural rights; specifically life, liberty, and property. ${ }^{54}$ It then follows that rights and liberties may be understood to differ subtly from privileges and immunities. I have no doubt that these terms were used quite often as synonyms during Blackstone's day and thereafter. Nevertheless, the terms may also be used more precisely with different emphases. Rights to some extent and liberties especially refer to natural rights, the moral freedom one enjoys independent from and prior to one's participation in civil society. Privileges and immunities, by contrast, refer to legal rights, specifically the positive laws and rights that protect and give determination to moral freedom in organized

51. 1 BLACKSTONE, supra note 18 , at $* 121$.

52. Id.

53. See LoCKE, supra note 50, at §§ 95-97, at 330-32. Consent is a problematic concept in social compact theory. For standard criticisms, see John Rawls, Justice as Fairness, 67 PHIL. REV. 178 (1958); Jeremy Waldron, John Locke: Social Contract Versus Political Anthropology, 51 ReV. PoL. 3, 6-8 (1989).

54. Accord BlaCKSTONE, supra note 18 , at *120-21, *125. 
political society. Privileges and immunities may also cover natural rights, but only inasmuch as the positive rights are so intertwined with the natural rights that it is impossible to separate the two.

Next, even though privileges and immunities secure natural rights, a people and government may reserve them, consistently with natural law, only to members of that political community. ${ }^{55}$ Richard Epstein finds this condition "dubious," finds it not "defensible as a matter of first principle under any system of limited government," and complains about the "tension between the positivist view that all rights emanate from the state, and the well-established natural law principle that on questions of title to land, prior in time is higher in right." does not presume as sharp a separation between the positivist and natural law principles as Epstein suggests. Ideally, the law of nature requires individuals in organized society to treat all their fellow men decently. But without such ties, domestic politics can go tribal. When it does, necessity steps in and excuses a people if it conquers its competitors and reserves the advantages of civil society only for its own members. Natural rights, Blackstone presumes, exist in a world of closed and competing political societies. As a matter of prudence, it is humane for free states to extend civil rights to aliens most of the time. But in cases of emergency, states may reserve the advantages of citizenship for individuals who have the loyalty to use those advantages with equal respect for fellow citizens - and the moral formation to use those advantages responsibly. ${ }^{57}$

Finally, although Blackstone refers to these positive law rights generally as "civil immunities," this genus covers two different species of particular privileges and immunities. With some overlap, "civil privileges” refer to entitlements that replicate in positive law the general substance of natural rights. "Private immunities" refer to the domains of noninterference English subjects enjoy as residual rights to do that which is not prohibited by particular civil laws.

If one weaves these various implications together, privileges and immunities associated with membership in the English compact presume something like the following. Men enjoy natural rights, especially rights to life, liberty, or property. These rights are not rights to particular state policies, particular outcomes, or particular personal results; they are

55. I thank Jeremy Rabkin for encouraging me to make this point more explicit.

56. Epstein, Of Citizens and Persons, supra note 10, at 341-42.

57. For other treatments of the tensions between natural international rights and the treatment of aliens, see Hines v. Davidowitz, 312 U.S. 52, 64-68 (1941), and Emmerich de Vattel, The LaW of Nations: Or the PRinciples of the LAW of

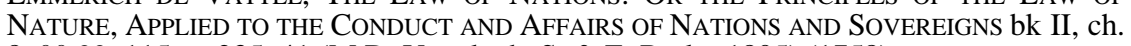
8, §§ 99-115, at 235-41 (M.D. Vattel ed., S. \& E. Butler 1805) (1758). 
rather domains of practical moral discretion, freedoms within which men may determine the ends for which their lives, liberties, and properties are used. In any case, privileges and immunities are positive laws, but with a substance informed by a common political morality. That common morality is informed - with some tension, to be sure-by two sources: the natural law and rights moral theory commonly associated with Locke and Blackstone, and the laws and customs that have traditionally defined, secured, and enlarged natural rights in English practice. By the same token, the government may legislate and enforce laws so as to protect privileges and immunities only for those who have consented to join the political society. The government and society may be bound to respect some minimal rules of decency set by the laws of nature in their dealings with non-members; but they may reserve complex legal protections for property, the rights to buy and sell goods, and other similar liberties for the citizenry alone.

\section{PRIVILEGES OR IMMUNITIES: THE AMERICAN TURN}

Blackstone lends weight to the fundamental rights readings of privileges and immunities because his discussion accords with the self-understanding of American statesmen and jurists after the American Revolution. Recall that Blackstone's discussion of privileges and immunities contained an ambiguity: Privileges and immunities were civil laws that specified the prescriptions of both natural law and English customary, legal, and political traditions. It is reasonable to suspect that, after the American Revolution, Blackstone's American students would stress the natural law over the English traditions. ${ }^{58}$

Americans who cut their teeth on Blackstone assumed that they were entitled to Blackstone's absolute rights on a par with English subjects living in England. Blackstone's "absolute” rights are the "alienable Rights" to which Americans referred in the Declaration of Independence. ${ }^{59}$ For Blackstone's American students, privileges and immunities were therefore the civil laws established "to secure these [unalienable] Rights.", even in a country organized around natural rights and "the Laws of

58. Or, to be more precise, they respected natural law and English traditions and practices consistent with natural law over English traditions and practices inconsistent with natural law.

59. The DeClaration OF INDEPENDENCE para. 2 (U.S. 1776).

60. Id. 
Nature and of Nature’s God," ${ }^{61}$ English and homegrown legal custom could still inform substantially the content of privileges and immunities. As the Declaration concedes, "[p]rudence ... will dictate that Governments long established should not be changed for light and transient Causes; and accordingly all Experience hath shewn, that Mankind" hold on long to "the Forms [of government] to which they are accustomed." 62 Notwithstanding their differences with the British monarchy and Parliament, American Revolutionaries regarded English custom, law, and political practices both as their own and as effective at securing natural rights.

In the period leading up to the Revolution, Americans used the terms privileges and immunities in this sense. Revolutionaries assumed that privileges and immunities established substantive standards of conduct, and they criticized the British and colonial governments for their failures to respect Americans' substantive rights. For example, Thomas Jefferson wrote two summaries remonstrating the English King and Parliament for violating the American colonists' natural rights. ${ }^{63}$ In a preface to one of them, Arthur Lee, an Englishman, argued:

[I]n justice bound to our country, and ourselves, and that fidelity we owe, Sir, to you, as our Sovereign, we openly declare, that the whole proceedings against our brethren in America, who are entitled, in common with ourselves, to the privileges of men, and the liberties, franchises, and protection of Englishmen, are in open violation of the natural laws of equity and justice. ${ }^{64}$

The privileges in this passage could refer to the local rights of Englishmen-but probably not, because the privileges are "the privileges of men." More important, the "proceedings against our brethren in America" are judged by the extent to which the English crown is respecting "the privileges of men" and "the natural laws of equity and justice.” Lee judges the English monarch by how well he secures civil rights that in turn are understood to secure universal natural rights.

Privilege and immunity were also used as markers for positive laws securing natural rights in the debate whether to scuttle the Articles of Confederation and ratify the Constitution of 1787 . For example, during Pennsylvania's ratification debate, Centinel argued, "Permit one of yourselves to put you in mind of certain liberties and privileges secured to you by the constitution of this commonwealth . . . before you

61. Id. at para. 1.

62. Id. at para. 2.

63. 2 The Works of Thomas JefFerson 54, 56 (Paul Leicester Ford ed., G.P. Putnam's \& Sons 1904).

64. Id. at 56 . 
surrender these great and valuable privileges up forever." ${ }^{65}$ In Federalist No. 2, John Jay spoke of the American people as follows: "To all general purposes we have uniformly been one people; each individual citizen everywhere enjoying the same national rights, privileges, and protection." Centinel and Publius disagreed about whether the new Constitution should be ratified. But they did agree on a common set of political and moral terms to wage the argument. By their usages, Centinel and Publius both suggested that privileges did not repeat strictly but rather differed slightly from rights or liberties. Equally important, by their language both assumed that citizens were entitled to ask whether the Constitution of 1787 did a better job securing both the moral freedom and the privileges than the Pennsylvania Constitution and the Articles of Confederation. Privileges were not merely whatever entitlements Pennsylvania happened to be providing Pennsylvania citizens at the time; privileges also set a normative standard for measuring how well Pennsylvania's civil laws secured Pennsylvanians' natural and customary substantive rights.

The Federalist's usage also confirms that privileges may be reserved only to citizens. The Federalist's argument for close and extended union could not take off without first taking for granted that the states have

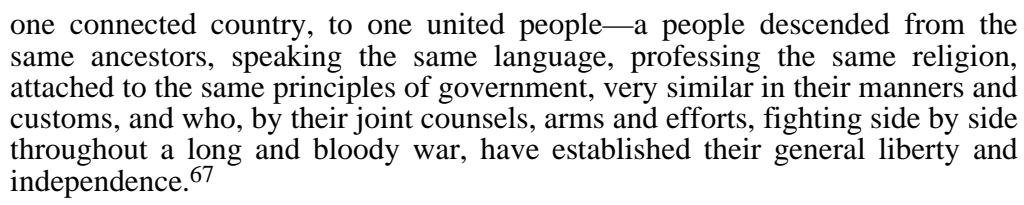
same ancestors, speaking the same language, professing the same religion, attached to the same principles of government, very similar in their manners and customs, and who, by their joint counsels, arms and efforts, fighting side by side throughout a long and bloody war, have established their general liberty and independence. ${ }^{67}$

While Publius presumed that The Federalist's audience subscribed to principles of natural law and rights, ${ }^{68}$ here he presumes that in political life, natural rights may be secured effectively by closed political communities. ${ }^{69}$ Similarly, in the now-standard 1823 property case

65. Centinel, LetTer I, reprinted in The Anti-Federalist 13, at 13 (Herbert J. Storing ed., Murray Dry abr., 1985).

66. The Federalist No. 2, at 5, 6-7 (John Jay).

67. Id. at 5, 6 .

68. See The Federalist No. 43, at 222, 229 (James Madison) (considering how, if the Constitution is ratified by the necessary majority but not unanimously, the new United States should comport themselves in relation to the non-ratifying states consistently with "the transcendent law of nature and of nature's God").

69. See also The Federalist No. 6, at 20, 25 (Alexander Hamilton) (criticizing theories of universal human rights, "which have amused us with promises of an exemption from the imperfections, the weaknesses, and the evils incident to society in every shape," and promising "to adopt as a practical maxim for the direction of our 
Johnson v. M'Intosh, when "abstract justice" favored Indian claims, in conflict with "those principles . . . which our own government has adopted" to govern the distribution of land, U.S. Supreme Court Chief Justice Marshall swallowed the injustice and sided with "the right of society, to prescribe those rules by which property may be acquired and preserved ....,70

The usages that Lee, Centinel, and Publius applied before the Revolution and during the debates over the Constitution carried forward into the antebellum period and into constitutional doctrine-particularly into some of the case law on privileges and immunities under the Comity Clause. Since we are not being exhaustive, let us consider Corfield v. Coryell simply because it is regarded as a leading case. ${ }^{71}$ Corfield, a Pennsylvania citizen, brought a boat into New Jersey territorial waters to fish for oysters in violation of a New Jersey statute reserving that fishing only to state citizens. When he sued Coryell, a New Jersey citizen, in trespass for seizing his boat pursuant to the New Jersey statute, the suit gave occasion for U.S. Supreme Court Justice Bushrod Washington, riding circuit, to determine whether the New Jersey statute unconstitutionally denied Corfield privileges or immunities in New Jersey. ${ }^{72}$ Washington specifically held—as will be considered at greater length below ${ }^{73}$ - that the right to fish for oysters in state waters is not a privilege or immunity of citizens of the several states. ${ }^{74}$ In the course of rendering that holding, however, Justice Washington rendered the following general observations about privileges and immunities:

The inquiry is, what are the privileges and immunities of citizens in the several
states? We feel no hesitation in confining these expressions to those privileges
and immunities which are, in their nature, fundamental; which belong, of right, to
the citizens of all free governments; and which have, at all times, been enjoyed
by the citizens of the several states which compose this Union, from the time of
their becoming free, independent, and sovereign. What these fundamental
principles are, it would perhaps be more tedious than difficult to enumerate.
They may, however, be all comprehended under the following general heads:
Protection by the government; the enjoyment of life and liberty, with the right to
acquire and possess property of every kind, and to pursue and obtain happiness
and safety; subject nevertheless to such restraints as the government may justly
prescribe for the general good of the whole. The right of a citizen of one state
to pass through, or to reside in any other state, for purposes of trade, agriculture,
professional pursuits, or otherwise; to claim the benefit of the writ of habeas
corpus; to institute and maintain actions of any kind in the courts of the state; to

political conduct, that we, as well as the other inhabitants of the globe, are yet remote from the happy empire of perfect wisdom and perfect virtue").

70. Johnson v. M’Intosh, 21 U.S. (8 Wheat.) 543, 572 (1823).

71. Corfield v. Coryell, 6 F. Cas. 546 (C.C.E.D. Pa. 1823) (No. 3230).

72. Id. at 546-47, 551.

73. See infra Part V.C.

74. See Corfield, 6 F. Cas. at 552. 
take, hold and dispose of property, either real or personal; and an exemption from higher taxes or impositions than are paid by the other citizens of the state; may be mentioned as some of the particular privileges and immunities of citizens, which are clearly embraced by the general description of privileges deemed to be fundamental . . . .75

Washington's observations track the Americanized understanding of Blackstone sketched in this and the previous Part. As used in the Comity Clause, privileges and immunities refer not to all possible claims of government benefit or protection, but to a narrow core of "privileges and immunities which are, in their nature, fundamental.” They are so fundamental because of the American turn-they "belong, of right, to the citizens of all free governments."76 Washington presumes that privileges and immunities belonging to citizens cover the same moral subject matter as Blackstone. What Blackstone covers by the absolute natural rights of life, liberty, and property, Washington covers with "life and liberty, with the right to acquire and possess property of every kind," and-again showing the Declaration of Independence's accents- "to pursue and obtain happiness and safety."77 When Washington turns from the general subject matter of privileges or immunities of citizenship to their specific determinations, he describes many in terms of negative liberties, or of legal rights giving structure and determination to those liberties: the rights to travel, establish a residence, trade, be free from arbitrary confinement, acquire and hold property, and so forth. Finally, by holding that the right to fish in a state's common waters does not count as a privilege or immunity that out-of-state citizens may claim in a sister state, Washington confirms that privileges and immunities that belong to citizens of the United States generally differ from "the rights which belong exclusively to the citizens of any ... particular state.",

Of course, Corfield still precedes the Civil War by more than a generation. Even so, at least some leading Republicans understood privileges or immunities of citizenship in the Blackstonian terms emphasized in Corfield. As just one example, consider a floor speech by Senator Lyman Trumbull in support of the Civil Rights Act of 1866.

75. Id. at 551-52.

76. Emphasis added.

77. See The DECLARATION OF INDEPENDENCE para. 2 (U.S. 1776) (declaring that all men are endowed with an unalienable right to "the Pursuit of Happiness" and that men are entitled to institute the form of government that "shall seem most likely to them to effect their Safety and Happiness").

78. Corfield, 6 F. Cas. at 552. 
While opining on the constitutionality of the Act, Trumbull discussed the Comity Clause and cited Corfield as the "most elaborate" judicial interpretation of the Clause. ${ }^{79}$ This fact is duly noted in other treatments of the Fourteenth Amendment's legislative history. ${ }^{80}$ Scholars do not note as often that Trumbull singled out Corfield because it applied to the concepts privileges, immunities, and American citizenship the general political and moral theory of the Declaration of Independence and Blackstone. Trumbull specifically quoted Blackstone to define civil liberty as "no other than natural liberty, so far restrained by human laws and no further, as is necessary and expedient for the general advantage of the public." 81 So at a minimum, even as late as the Civil War, Blackstone had not entirely given way to homegrown American treatise writers. Moreover, Trumbull praised Corfield's discussion of privileges and immunities specifically because Corfield related privileges and immunities back to Blackstone and the Declaration. In the United States, Trumbull continued, Blackstone's definition of liberty "is the liberty to which every citizen is entitled; that is the liberty which was intended to be secured by the Declaration of Independence and the Constitution of the United States originally." 82

\section{The ORIGINAl Public MEANing OF the PRIVILEGES OR IMMUNITIES CLAUSE}

Again, one would need to canvas a huge range of practical legal documents, consider contrary evidence, and account for changing word usages before concluding that privileges and immunities in the Fourteenth Amendment track Blackstone's usages. All the same, Blackstone's Commentaries do make more comprehensible and respectable fundamental rights interpretations of the Privileges or Immunities Clause. The following two Parts suggest the implications for two different kinds of originalist inquiry. This Part focuses on implications for the Privileges or Immunities Clause's plain meaning. The next Part considers implications for general understandings, abstracted from the Clause's specific public textual meaning, of the Clause's likely meaning and effect at ratification.

79. Cong. GloBe, 39th Cong., 1st Sess. 474 (1866) (statement of Sen. Trumbull).

80. See, e.g., Harrison, supra note 15, at 1402-03.

81. Cong. GloBe, 39th Cong., 1st Sess. 474 (1866) (statement of Sen. Trumbull) (quoting, with minor variations, 1 BLACKSTONE, supra note 18 , at *121).

82. Id. 


\section{A. Privileges or Immunities}

Scholarship on the Privileges or Immunities Clause sorts itself out into three general interpretations of the Privileges or Immunities Clause. ${ }^{83}$ Two have already been mentioned, the fundamental rights approach and the nondiscrimination approach. A third is the "incorporationist" approach proposed by Justice Black ${ }^{84}$ and more recently by Michael Kent Curtis ${ }^{85}$ and Akhil Amar. ${ }^{86}$ This approach holds that the Privileges or Immunities Clause incorporates by reference and applies to the states some or all of the individual rights that the Bill of Rights makes applicable to the federal government. ${ }^{87}$ Blackstone's treatment of privileges and immunities provides significant support to the fundamental rights interpretation, qualified support to the incorporationist reading, and significant challenges to the nondiscrimination reading.

\section{Fundamental Rights}

Blackstone's treatment confirms the fundamental rights reading in two important respects. Blackstone provides a point of contact with AngloAmerican natural law and natural rights political morality. Contemporary judicial opinions and scholarship are written by authors who have little or no direct familiarity with this political morality. It is quite easy for such authors unsuspectingly to read terms like privileges and immunities anachronistically or out of context. When Blackstone expounds on privileges and immunities associated with membership in a free society, his exposition is elaborate enough to help modern readers identify a conceptual context-membership in a free political society-in which

83. As a matter of constitutional doctrine, the Privileges or Immunities Clause applies to the states only a few core rights of citizenship that the Constitution of 1787 applies to the federal government expressly or by implication. See The Slaughter-House Cases, 83 U.S. (16 Wall.) 36 (1872). I assume the Slaughter-House Cases do not accurately reflect the Privileges or Immunities Clause's original meaning for reasons explained by John Harrison, supra note 15, at 1414-16.

84. Adamson v. California, 332 U.S. 46, 71-72 (1947) (Black, J., dissenting).

85. Michael Kent Curtis, No State Shall Abridge: The Fourteenth AMENDMENT AND THE BILL OF RigHTS 64-65 (1986).

86. AKhil Reed Amar, AmericA's Constitution: A Biography 387-89 (2005); AMAR, supra note 19, at 166-69 (1998).

87. See Adamson, 332 U.S. at 71-72. 
privileges and immunities had definitions as terms of art different from other usages.

Separately, Blackstone makes Corfield v. Coryell more respectable and

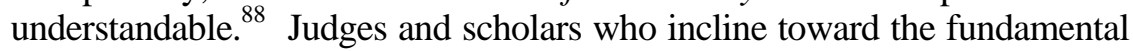
rights reading lean heavily on Corfield to explain how privileges and immunities were understood as terms of art in contexts associated with citizenship during Reconstruction. Justice Thomas has called Corfield a "landmark opinion,",9 and Professor Siegan called it a "famous pronouncement on the meaning of the privileges and immunities clause of article IV."90 Scholars who disagree suggest that Corfield was something of an outlier in antebellum case law on constitutional privileges and immunities. ${ }^{91}$ Or, even if Corfield was widely cited and respected, critics suggest, Washington's opinion seems "loose language"-incoherent dicta unable to sustain the weight the fundamental rights reading requires of it. ${ }^{92}$

Blackstone's exposition on privileges and immunities does not refute these criticisms by itself, but it does point the way toward such a refutation. On one hand, as the previous Part explained, Blackstone's exposition helps make important parts of Washington's opinion more coherent, so Corfield seems more than mere loose language. On the other hand, Blackstone's exposition provides a useful conceptual razor to cut the least sensible parts of Corfield from the most sensible. For example, Corfield is often criticized because at one point Justice Washington suggested that the right to vote may count as a privilege or immunity of general United States citizenship. ${ }^{93}$ This suggestion, critics of Corfield are quick to point out, went against the weight of antebellum law. ${ }^{94}$ Blackstone's exposition helps explain why, in context of the natural law and rights political morality that prevailed during Reconstruction, Corfield erred in how it classified the right to vote. A privilege or immunity of citizenship refers to a positive law right securing or specifying the free exercise of an absolute personal right, like life, liberty, or property. In Blackstone's conception, the right to vote

88. I am grateful to Larry Solum for prompting me to make this connection more explicit. See Posting of Lawrence Solum to Legal Theory Blog, Larry Solum, "Bezanson on Art and the Constitution," Legal Theory Blog, May 8, 2008, available at http://lsolum.typepad.com/legaltheory/2008/05/bezanson-on-art.html (May 8, 2008, 06:22 EST).

89. Saenz v. Roe, 526 U.S. 489, 524-25 (1999) (Thomas, J., dissenting).

90. SIEGAN, supra note 8 , at 48.

91. See, e.g., MALTZ, supra note 17, at 32 (portraying Corfield as a "widely-cited" but "somewhat equivocal exception" to the dominant trend antebellum Comity Clause case law).

92. CURRIE, supra note 14, at 347 n.131.

93. See 6 F. Cas. 546, 552 (C.C.E.D. Pa. 1823) (No. 3230).

94. See, e.g., Harrison, supra note 15, at 1417. For case law contrary to Corfield on this point, see Campbell v. Morris, 3 H. \& McH. 535, 554 (Md. 1797). 
does not secure an absolute right, it is instead a relative right, a right created in and by a social group for social ends. ${ }^{95}$ At the same time, Blackstone's exposition helps explain why leading jurists might regard Corfield as "good law" generally even if it applied general principles mistakenly in the specific case of the right to vote.

For example, in floor statements on a draft of the Fourteenth Amendment, Senator Jacob Howard cited Corfield as "some intimation of what will probably be the opinion of the judiciary" about the Privileges or Immunities Clause, and he called Justice Washington a "very learned and excellent judge." ${ }^{96}$ In the next Congress, however, Senator Howard took the floor to insist strenuously that the Fourteenth Amendment had not made the right to vote a privilege or immunity of United States citizenship. ${ }^{97}$ Maybe Howard was trying to have it both ways. Legislators often repudiate portions of bills that turn out later to be unpopular as laws. Yet Blackstone's exposition clarifies why Senator Howard's statements might both have been perfectly sincere and consistent with one another.

Blackstone's exposition on privileges and immunities does call previous fundamental rights interpretations of the Privileges or Immunities Clause into question in some respects. Some previous interpretations - for example, Professor Siegan's ${ }^{98}$ - suggest that the Privileges or Immunities Clause protects fundamental rights on terms at least similar and perhaps identical to a theory of substantive due process organized around natural law fundamental rights. Blackstone's treatment suggests otherwise. The Fourteenth Amendment's Due Process and Equal Protection Clauses protect "person[s]," while the Privileges or Immunities Clause protects "citizens of the United States." 99 The Fourteenth Amendment codifies a distinction suggested in Blackstone and recognized by sources canvassed in Part IV:100 A free and republican government needs to respect some general standards of natural law when it deals with aliens, but it may secure natural rights to its citizens with a stronger and more detailed set of positive legal protections. It would take exhaustive research, beyond the

95. See 1 BlacKSTONE, supra note 18 , at $* 119$.

96. CONG. GLOBE, 39th Cong., 1st Sess. 2765 (1866) (statement of Sen. Howard).

97. Cong. Globe, 40th Cong., 3d Sess. 1003 (1869) (statement of Sen. Howard).

98. See SIEGAN, supra note 8, at 66 (reading Representative Bingham's floor speeches to treat privileges or immunities, equal protection, and due process "interchangeably to condemn oppressive state legislation”).

99. U.S. CONST. amend. XIV, § 1.

100. See supra notes 55-57 and 67-70 and accompanying text. 
scope of this essay, to draw the lines between the minimal standards of natural law applicable to aliens and the standards set by privileges or immunities of republican citizenship. But Blackstone's Commentaries provide important evidence suggesting the distinction matters in the original public meaning of the Fourteenth Amendment. Richard Epstein has recently highlighted textual and structural reasons why the citizenperson distinction matters. ${ }^{101}$ Blackstone's Commentaries provides additional evidence reinforcing that distinction.

\section{Incorporation}

Blackstone's treatment of privileges, immunities, and natural rights provides qualified support for incorporationist readings of the Privileges or Immunities Clause. In short, the Privileges or Immunities Clause may make applicable on the states many rights guarantees enumerated elsewhere in the Constitution. But to the extent the Clause does incorporate constitutional rights guarantees, it does so not because the rights are constitutional but because the Constitution secures fundamental moral rights.

Corfield suggests this general relation. The right "to claim the benefit of the writ of habeas corpus"102 is listed in Corfield as an example of a privilege or immunity; that right is enumerated in the U.S. Constitution. ${ }^{103}$ Yet Corfield also includes among privileges and immunities the otherwise unenumerated rights to travel for commercial purposes and to acquire property. ${ }^{104}$ Blackstone's Commentaries confirms the same relation with the example of habeas corpus. The writ of habeas corpus is cited both as a privilege in the unwritten English constitution ${ }^{105}$ and a necessary security for the absolute natural right of personal liberty. ${ }^{106}$

Although this essay cannot confirm the relation comprehensively, there is at least some evidence that American jurists understood privileges in the same way: Many constitutional rights provided examples of citizen privileges or immunities, but constitutional rights did not necessarily exhaust the class of privileges and immunities. For example, in a series of Resolves preceding the Revolutionary War, the Massachusetts people proclaimed:

101. See Epstein, Of Citizens and Persons, supra note 10, at 340-49.

102. Corfield v. Coryell, 6 F. Cas. 546, 552 (C.C.E.D. Pa. 1823) (No. 3230).

103. See U.S. ConsT. art. I, § 9, cl. 2.

104. See Corfield, 6 F. Cas. at 552.

105. See 1 BLACKSTONE, supra note 18 , at $* 124$.

106. See id. at $* 132-33$. 
Resolved, That there are certain essential Rights of the British Constitution of Government, which are founded in the Law of God and Nature, and are the common Rights of Mankind-Therefore ... Resolved that no Man can justly take the Property of another without his Consent ... . this inherent Right, together with all other essential Rights, Liberties, Privileges and Immunities of the People of Great Britain have been fully confirmed to them by Magna Charta . . . 107

The Resolves seem to confirm the incorporation reading. Eminent domain is a privilege here, and eminent domain limitations are enumerated in the Bill of Rights in the Fifth Amendment. ${ }^{108}$ But properly read, the Resolves suggest that privileges cover not only eminent domain limitations but any unenumerated and "inherent"-natural and substantive-right that was confirmed to the British people by British legal tradition. If this example is representative, a right need not be enumerated to qualify as a privilege or immunity of citizenship.

\section{Nondiscrimination}

Blackstone's justification for privileges and immunities creates stronger theoretical challenges to the last interpretation: nondiscrimination. Under this interpretation, the Privileges or Immunities Clause applies only to subjects that have traditionally been understood as fundamental rights - especially "private law rights of property ownership, contractual capacity, and personal security, and access to governmental mechanisms that protect those primary rights." ${ }^{109}$ As to those subjects, states have substantial discretion to structure state common law as they wish: privileges and immunities need not secure "minimum Lockean freedoms but rather full specification of state law on basic subjects." ${ }^{110}$ The status of this law as privileges and immunities imposes a side constraint on state lawmaking. States remain generally free to specify the personal and possessory interests that shape the law of tort, contract, and property, as long as they do not discriminate unjustifiably on the basis of race or other impermissible group characteristics. ${ }^{111}$

107. The Massachusetts Resolves, October 29, 1765, reprinted in PROLOGUE TO Revolution: SOURCES AND DoCumenTS ON THE STAMP ACT CRISIS, 1764-1766, at 56 (Edmund S. Morgan ed., 1959). For other colonial references, see the sources collected by Justice Thomas in Saenz v. Roe, 526 U.S. 489, 523-24 n.3 (1999) (Thomas, J., dissenting).

108. See U.S. Const. amend. V.

109. Harrison, supra note 15, at 1416; see CURRIE, supra note 14, at 347 n.131.

110. Harrison, supra note 15, at 1418.

111. See CURRIE, supra note 14, at 346-49; Harrison, supra note 15, at 1410-33. 
This interpretation fairly captures the understanding that states have substantial discretion to structure local property and personal regulations to suit local conditions and opinions. It also captures the fact that the Privileges or Immunities Clause bars state laws that discriminate by group characteristics in the protection of basic personal and property based liberties. At the same time, this interpretation abstracts significantly from the Blackstonian understanding that influenced American law throughout much of the nineteenth century. Even if each of the states had substantial discretion to write local laws for local conditions, on Blackstone's understanding all the states would in their own ways be aiming to secure similar natural rights. On that understanding, a state could use its regulatory powers to deny natural rights based privileges or immunities without discriminating on the basis of race.

Let me illustrate by using the facts and a few simple variations of the facts of the Slaughter-House Cases, in which the U.S. Supreme Court read the Privileges or Immunities Clause to be a dead letter. ${ }^{112}$ In the case as litigated, the Louisiana state government granted to a Louisiana resident an exclusive and private monopoly over cattle slaughtering within New Orleans city limits. ${ }^{113}$ The fundamental rights and nondiscrimination interpretations dovetail on two propositions: The right to practice the trade of cattle slaughtering counts as a fundamental right; and if, contrary to the real facts, Louisiana had limited the slaughtering practice to whites or white Louisianans, it would without a doubt have made a law abridging the privileges or immunities of non-white citizens.

The fundamental rights and nondiscrimination approaches diverge on whether a law conferring an exclusive monopoly without regard to race abridges a privilege or immunity of citizenship. Under the nondiscrimination approach, citizens have as privileges and immunities whatever "rights [are] defined by state positive law," and the Fourteenth Amendment does not require that these rights be structured to secure "Lockean natural rights defined without reference to the law of any state."114 So the excluded butchers have no claim to treatment by any standard they are not already getting under the Louisiana monopoly law.

If Blackstone is a reliable guide, however, there is not such a sharp separation between positive and natural law. To begin with, thanks to Blackstone and other English and American treatise writers, American common law in its main features secured rights with "Lockean" substantive content. Local common law was not uniformly "Lockean," and local statutes could and often did break from the model, but the

112. 83 U.S. (16 Wall.) 36 (1873).

113. See id. at 36-44.

114. Harrison, supra note 15, at 1419. 
common law that filled in the gaps made a substantive commitment toward structuring liberty and property rights to encourage the free, equal, and concurrent use of individual talents and energies toward productive ends. Consider how general American common law would have regarded a claim by any slaughterhouse in the New Orleans area to be the sole and exclusive butcher as a matter of common law. American common law, following English law, presumed as a "general principle.. . that every man may fix what price he pleases upon his own property or the use of it," and it did so specifically to encourage every owner to "make the most of his own." 115 Or, perhaps that would-be monopolist and local residents might have tried to shut down competing butchers on the ground that their slaughterhouses posed health or safety risks to nearby residents. Under general principles of nuisance that prevailed through the mid-twentieth century, the complaining parties would have needed to show that the slaughterhouses created a demonstrable health or safety threat, and that shutting the slaughterhouses down was a proportionate response to the threat. ${ }^{116}$

Excluded butchers thus had privileges or immunities-precisely, a legal immunity to practice the butchering trade in the domain of practical discretion left open by the absence of common carrier or nuisance liability. But this immunity was not an immunity merely by virtue of being a civil specification of a general natural right. To count as a Blackstonian immunity, it needed to secure meaningfully the substance of a natural right to liberty and property as understood in Anglo-American political morality-a domain of discretion structured to encourage different individuals to use similar industrious and creative talents productively. As Chancellor James Kent explained in his Commentaries on American Law, "[t]he exclusive right of using and transferring property, follows as a natural consequence, from the perception and admission of the right itself." ${ }^{117}$ That right, in turn, followed from the fact that "[t]he sense of property is graciously

115. Allnutt v. Inglis, 104 Eng. Rep. 206, 208, 210 (K.B. 1810).

116. See Eric R. Claeys, Public-Use Limitations and Natural Property Rights, 2004 Mich. St. L. REV. 877, 914-19 [hereinafter Claeys, Public-Use Limitations]; Eric R. Claeys, Takings, Regulations, and Natural Property Rights, 88 CORNELl L. REV. 1549, 1577-81 (2003) [hereinafter Claeys, Takings].

117. KENT, supra note 37, at 257-58. 
implanted in the human breast, for the purpose of rousing us from sloth, and stimulating us to action ...."

The same principles would apply to statutory schemes. The state might choose to specify the natural rights of its citizens by statutory law_-say, by a Continental civilian code like Louisiana's. Or, it might rely generally on the common law, but then pass a few prophylactic statutes regulating particularly dangerous or problematic threats to the public health, safety, or public morals. ${ }^{119}$ State statutes could differ in the details, to suit local political opinions, geographical conditions, and other relevant considerations. A local statute could therefore also generally grant privileges or immunities in the Slaughter-House Cases, as long as it made a reasonable effort to secure to potential cattle slaughterers a domain of non-interference in which to practice butchering productively, consistent with public health and other similar obligations, in competition with other butchers.

When privileges and immunities of citizenship are understood in this manner, the constitutional limitations follow in straightforward fashion. Louisiana could impose price or competition restrictions on the slaughtering trade if the trade was part of a natural monopoly, ${ }^{120}$ but that seems unlikely for a business as easy to enter as slaughtering. ${ }^{121}$ Louisiana could claim a legitimate interest in stopping cattle from being slaughtered in conditions that could spread disease or food poisoningbut the state could advance this interest in several ways short of restricting the slaughtering business to a monopoly. ${ }^{122}$ With privileges and immunities so understood, the Louisiana law abridged an immunity of United States citizens.

Nondiscrimination scholars resist this line of argument for a few reasons. One misconception holds that any system of positive law can count as a privilege or immunity because "it is in the positive law that

118. Id. at 257.

119. See, e.g., William J. NovaK, The People's Welfare: LaW and Regulation IN NINETEENTH-CENTURY AMERICA (1996).

120. But see People ex rel. Annan v. Walsh, 22 N.E. 682, 684-89, 692-94 (N.Y. 1889) (Peckham, J., dissenting), aff'd, Budd v. People, 143 U.S. 517 (1892) (arguing that states could impose common carrier regulations not on natural monopolies but only on legal monopolies).

121. See The Slaughter-House Cases, 83 U.S. (16 Wall.) 36, 88-89 (1873) (Field, J., dissenting) ("The naked case, unaccompanied by any public considerations, where a right to pursue a lawful and necessary calling, previously enjoyed by every citizen, and in connection with which a thousand persons were daily employed, is taken away and vested exclusively for twenty-five years, for an extensive district and a large population, in a single corporation ....”).

122. See id. at 103-08 (Field, J., dissenting) (considering and rejecting the rationale suggested in text). 
[a] natural right becomes meaningful.."123 True, in most natural law and rights theories, the institution of positive law usually secures natural rights even without regard to the content of the natural law. For the purposes of understanding the original meaning of the Privileges or Immunities Clause, however, that is not the question. The question is instead how the Clause's likely reasonable readers understood privileges and immunities to refer to any positive laws on covered topics, regardless of content, or to positive laws that made some minimal efforts to approximate the prescriptions of Blackstone and other natural rights jurists. Nondiscrimination scholars doubt this latter possibility. They are skeptical that privileges or immunities hardwire into constitutional law so-called "Lockean natural rights defined without reference to the law of any state." ${ }^{124}$ Yet that skepticism begs the question. If privileges and immunities are connected as explicitly to a specific substantive conception of natural law and rights as Blackstone's treatment suggests, ${ }^{125}$ the terms would and should have been understood by their reasonable intended audience to lock in that substantive conception. Other nondiscrimination scholars then raise the "ink blot" criticism ${ }^{126}$ - they doubt whether moral theories can make specific substantive prescriptions. Although I do not profess to make any claims about constitutional moral theories generally, I can say with certainty that this criticism does not stick to the natural law and rights tradition associated with Locke and Blackstone. In previous scholarship, I have shown that this tradition gave nineteenth-century American due process, takings, and Contracts Clause case law determinate focus. ${ }^{127}$

This essay cannot settle the former two criticisms. Yet there is at least some evidence suggesting that privileges and immunities refer to civil rights securing natural rights to life, liberty, and property as understood within a substantive theory of fundamental rights informed by Locke, Blackstone, Kent, and other similar theorists and jurists.

123. Harrison, supra note 15, at 1419 n.138.

124. Id. at 1419.

125. See supra notes $48-50$ and accompanying text.

126. BORK, supra note 13, at 166.

127. See Claeys, Public-Use Limitations, supra note 116, at 914-28; Claeys, Takings, supra note 116, at 1574-1644; see also MALTZ, supra note 17, at 86-87 (concluding that Justice Field's dissenting opinion in the Slaughter-House Cases accorded with free labor natural rights principles reflected in important antebellum legal precedents). 


\section{B. Abridging}

The verb used in the Privileges or Immunities Clause confirms the same relation. The Privileges or Immunities Clause's operative verb is abridging. ${ }^{128}$ Definitionally and conceptually, the verb abridge presumes that the thing that is not supposed to be abridged has a substance independent from the government action abridging it.

At the founding, through the Civil War, and as a legal and moral term of art, the verb abridge was used quite often as a synonym for diminish and an antonym of enlarge. Blackstone's Commentaries illustrate how abridge operates in the context of legal practice built on natural rights moral philosophy. In the same passage in which he introduces his readers to privileges or immunities, Blackstone declares:

[A]s there is no other known method of compulsion, or of abridging man's natural free will, but by an infringement or diminution of one or other of these important rights, the preservation of these inviolate may justly be said to include the preservation of our civil immunities in their largest and most extensive sense. 129

English subjects' civil immunities - their privileges and immunitieshave prepolitical substance because they are the determinations, under English positive law, of English subjects' moral rights in the state of nature. English law does not create or establish those immunities-it "preserv[es]" immunities Englishmen already had by virtue of the laws of nature. Those immunities are legal expressions of a moral interest with which English subjects are endowed, namely, "free will.” This free will is not equivalent to arbitrary or unlimited license; in the passage that Senator Trumbull picked up later, Blackstone defines “[p]olitical . . . or civil, liberty, which is that of a member of society, [as] no other than natural liberty so far restrained by human laws (and no farther) as is necessary and expedient for the general advantage of the publick." ${ }^{130}$ Those limitations justify a government's actions when it defines citizens' general domain of noninterference in positive law, or when it restrains one person from invading another's domain. The substantive right and its limitations define when actors-public or private-diminish that substantive moral interest in "free will," by "infring[ing]" or “dimin[ishing]” English subjects' civil privileges or immunities. When such acts diminish Englishmen's free will, Blackstone's primary term of art is compel. When such acts that diminish freedom without direct

128. U.S. Const. amend. XIV, § 1.

129. 1 BLACKSTONE, supra note 18 , at *129.

130. Id. at *121; see supra note 81 and accompanying text. 
compulsion, Blackstone's term is abridging. Abridging is the backstop term for all direct or indirect limitations on moral freedom.

The Constitution, as amended through the Fourteenth Amendment, uses abridge more or less consistently with Blackstone's usage. The most powerful illustration for this understanding is in the First Amendment. The Free Speech Clause orders Congress to make "no law abridging the freedom of speech." "31 Modern textualists are tempted to put the emphases on "no law" and "speech," so that the Clause bars virtually all speech regulations. But read against the context of natural law and rights theory, the emphases ought to be on abridging and freedom. By speaking in terms of a freedom of speech, the First Amendment does not establish a new right but rather declares the existence of a natural right - a moral and prepolitical interest preceding the Constitution. This right is a negative liberty to determine the use and enjoyment of one's speech, consistent with the equal rights of others-for example, to an accurate reputation - and the legitimate needs of the public - to a decent public morality. As Philip Hamburger has explained, at the founding, when politicians, journalists, or preachers spoke about laws affecting speech, they overwhelmingly assumed that governments could regulate speech-by passing positive laws providing real life determination to the natural law limitations not to use one's speech to injure the natural rights of others or the legitimate interests of the public. ${ }^{132}$ That is why governments could regulate ${ }^{133}$ seditious libel, for example, without abridging speech.

Consider how John Marshall justified the seditious libel laws in the Alien and Sedition Act. ${ }^{134}$ Marshall considered the possibility that the First Amendment literally said no law could restrain speech rights. ${ }^{135}$ For Marshall, if the First Amendment had meant to codify the "no law" reading, Congress should have used the verb respecting, as it did in the

131. U.S. CONST. amend. I.

132. See Philip A. Hamburger, Natural Rights, Natural Law, and American Constitutions, 102 YALE L.J. 907, 944-55 (1993).

133. To be precise, at least the Federalists assumed the government could regulate seditious libel.

134. John Marshall, Report of the Minority on the Virginia Resolutions (Jan. 22, 1799), in 5 The Founders' Constitution 136 (Philip B. Kurland \& Ralph Lerner eds., 1987). Although Henry Lee is often credited with authoring this minority report, Marshall was the likely author. See Kurt T. Lash \& Alicia Harrison, Minority Report: John Marshall and the Defense of the Alien and Sedition Acts, 68 OHIO ST. L.J. 435, 435-46 (2007).

135. Marshall, supra note 134, at 138. 
Establishment Clause-not the verb abridging. ${ }^{136}$ Marshall understood the freedoms of speech and press to refer to "a liberty to publish, free from previous restraint, any thing [sic] and every thing [sic] at the discretion of the printer only, but not the liberty of spreading with impunity false and scandalous slanders which may destroy the peace and mangle the reputation of an individual or of a community." ${ }^{\text {,37 }}$ For Marshall, those limitations on slander and sedition came from natural law and English common law. A government action did not abridge free speech if it restrained exercise of "the liberty of spreading ... false and scandalous slanders." That liberty fell outside the substance of the Free Speech Clause.

The other relevant use of abridge in the Constitution as of the Civil War is Section Two of the Fourteenth Amendment, which specifies: "[W]hen the right to vote at any [specified] election . . . is denied to any of the male inhabitants of such State, being twenty-one years of age, and citizens of the United States, or in any way abridged . . . the basis of representation therein shall be reduced ...." ${ }^{\text {"138 }}$ Here, the term abridged is read most reasonably as sweeping in any government action diminishing the right to vote without technically denying it. Section Two varies slightly from the template provided in the First Amendment and in Section One of the Fourteenth Amendment. The substantive right in Section Two is not a fundamental natural right but rather the right to vote, specifically the right of males twenty-one and older to vote, as declared in Section Two itself. John Harrison has relied on this fact to conclude that abridge may mean in some contexts "discriminate formally against." ${ }^{139}$ In his interpretation, the vote is a creature of state government and will be more or less meaningful depending on what officers are elected or appointed. ${ }^{140}$ That said, to determine what abridged means in context, it does not matter for what officers the voter may vote. What does matter is, whatever officers the state makes electable, whether the state allows all males who are twenty-one or older to vote. That baseline has a substance independent of state law in Section Two of the Constitution. ${ }^{141}$ Important here, the right to vote may therefore be abridged - that is, diminished, in the same sense in which freedom of speech may be diminished by laws contrary to the First Amendment.

The implications for Section One of the Fourteenth Amendment should by now be clear. Textually, state laws that respect, define,

136. Id.

137. Id.

138. U.S. Const. amend. XIV, § 2.

139. See Harrison, supra note 15, at 1421.

140. Id. at $1420-21$.

141. U.S. Const. amend. XIV, § 2. 
protect, or enlarge the general substance of fundamental natural Blackstonian rights regulate such privileges and immunities. According to Corfield's description, such regulations limit the free exercise of rights as necessary to "subject [freedom] to such restraints as the government may justly prescribe for the general good of the whole."142 State laws that restrain those rights more than necessary for "the general good of the whole," however, abridge such rights, in violation of the Privileges or Immunities Clause.

Of course, it could be that, by Reconstruction, the term abridge had a secondary meaning, similar to the one Harrison proposes, something like "withhold unjustifiably a benefit provided to a race or another class." Scholars have found examples in which Reconstruction era actors used abridge in this sense. ${ }^{143}$ For example, in debates over the Fourteenth Amendment, Representative Thomas Eliot paraphrased a draft version of the Privileges or Immunities Clause to mean "the power to prohibit State legislation discriminating against classes of citizens." " Eliot's usage, however, is consistent with both the nondiscrimination and the fundamental rights readings of the Privileges or Immunities Clause. Again, under the fundamental rights reading, a state may abridge privileges or immunities not only by restricting the property and trade rights of virtually all citizens, as happened in the Slaughter-House Cases, but also by securing and ordering those rights for one race or class of citizens and denying them to others. Thus, when Reconstruction era speakers used abridgment interchangeably with race discrimination or class discrimination, their usages do not necessarily support the nondiscrimination reading. To provide that support, the usages would need to confirm that the speaker used abridgment specifically to bar state race or class discrimination without barring generally interventionist state property or contract regulation.

\section{Entitled and the Comity Clause}

One final piece of textual evidence comes from the Constitution of 1787, specifically the Comity Clause. The diligent originalist must be

142. Corfield v. Coryell, 6 F. Cas. 546 (C.C.E.D. Pa. 1823) (No. 3230). 24.

143. See CuRRIE, supra note 14, at 346 \& n.126; Harrison, supra note 15, at 1423-

144. Cong. Globe, 39th Cong., 1st Sess. 2511 (1866) (statement of Rep. Eliot), quoted in Harrison, supra note 15, at 1423. 
careful here, and discount for the possibility that privileges and immunities changed as constitutional terms of art from 1787 to 1868. Even so, it is at least worth considering whether the terms privileges and immunities are structurally consistent with the Comity Clause and the Privileges or Immunities Clause. If the originalist is focusing on original public meaning, structural continuity provides some evidence, if weak, to prefer the fundamental rights interpretation over the nondiscrimination interpretation.

The key conceptual insight comes from the text of the Comity Clause: "The Citizens of each State shall be entitled to all Privileges and Immunities of Citizens in the several States."145 The verb in this Clause is entitled. Entitled does no work to determine what particular rights are enjoyed by the citizens covered. All the verb does is declare that citizens covered have whatever rights that come within the ambits of privileges or immunities. For the Comity Clause to have coherent meaning, the terms privileges and immunities must have enough internal content to say what is covered in a right and when a state action respects or infringes the right. In other words, privileges and immunities must presuppose a substantive theory of rights, which in turn delineates a substantive theory of government regulation. The nondiscrimination reading cannot satisfy these demands-at least, not without relying through the backdoor on a substantive theory of rights and regulation. But a substantive theory of constitutional privileges and immunities is basically a fundamental rights theory of the same.

The simplest example is Corfield, which, again, held that the right to fish for oysters in New Jersey territorial waters did not count as a privilege or immunity under the Comity Clause. ${ }^{146}$ Under a fundamental rights reading, this view is correct. Fundamental property and trade rights refer to the positive laws that secure to individuals their natural rights to be let alone, to determine the ends to which they may apply their property and commercial liberty. ${ }^{147}$ A state does not need to extend to out-of-state citizens usufructuary rights to extract common state resources in order to protect their rights to enjoy their economic liberties without interference. ${ }^{148}$ So the fundamental rights reading cleanly separates the Comity Clause from state decisions to provide special

145. U.S. CONST. art. IV, § 2, cl. 1.

146. 6 F. Cas. 546, 552 (C.C.E.D. Pa. 1823) (No. 3230).

147. See supra notes 50-52 and accompanying text.

148. See Corfield, 6 F. Cas. at 552 ("[W]e cannot accede to the proposition ... that in regulating the use of the common property of the citizens of such state, the legislature is bound to extend to the citizens of all the other states the same advantages as are secured to their own citizens.”). 
benefits or subsidies to its citizens. ${ }^{149}$ It does so because the fundamental rights content of privileges and immunities excludes government benefits or subsidies. The verb entitled never comes into play.

The nondiscrimination view asks first whether Corfield is claiming a fundamental right, and if so, it then asks whether New Jersey is providing access to that right to out-of-state citizens on justifiably equal terms as to in-state citizens. At first blush, this approach seems to generate the same result as the fundamental rights approach-oyster fishing is not a fundamental right. On closer inspection, however, the inquiry is much more complicated. David Currie asserts that Corfield excludes rights claims from the Comity Clause "unless the right was fundamental," ${ }^{150}$ but he does not explain how a judge is supposed to determine whether a right is fundamental. If a right is fundamental because it is fundamental in commonly shared principles of natural law and rights articulated in the Declaration of Independence and elsewhere, then Currie's reading endorses the fundamental rights approach-except through the backdoor, and only selectively, in a context where fundamental rights analysis limits and does not enlarge judicial discretion.

Alternatively, fundamental rights analysis might not appeal to natural law and rights principles directly. John Harrison sketches this possibility. Again, he suggests that security, contractual capacity, and property are subjects of fundamental rights. ${ }^{151}$ Yet Harrison does not explain why these are the topics of fundamental rights. Nor does he explain why private law property rights are fundamental while public law entitlements to state property are not fundamental. For example, Harrison asserts that the rights claimed in Corfield related not to "some well-known fundamental right, but oysters." 152 He does not substantiate this assertion. A usufructuary interest in harvesting oysters certainly sounds like a property right, and therefore part of the "full specification of state law on basic subjects" covering "property." 153 Perhaps New Jersey common law builds in some "minimum theory of Lockean freedoms"154 to draw the line

149. However, this is only true as long as the benefits or subsidies do not restrain out-of-state citizens' rights to be let alone.

150. CURRIE, supra note 14, at 347 n.131; see also Harrison, supra note 15, at 1399 (reading Corfield to "involve[] not some well-known fundamental right" but merely "oysters").

151. Harrison, supra note 15, at 1422.

152. Id. at 1399.

153. Id. at 1418,1422

154. Id. at 1418. 
between private property rights on one hand and state open-access or commons regimes on the other, and perhaps usufructuary rights to harvest oysters in public waters fall on the latter side of the line. If the nondiscrimination interpretation makes that move, however, it is parasitic on the fundamental rights principles latent in New Jersey common law.

If, however, the nondiscrimination interpretation does not appeal to background substantive property theory, then it is not clear how one distinguishes fundamental rights from state benefits. At that point, outof-state citizens may plausibly claim they are "entitled" to whatever positive law benefits states confer on their own citizens. No surprise that, more than a century later, after background Lockean principles ceased to influence the law, the U.S. Supreme Court declared invalid a state shrimping statute similar to the oyster law challenged in Corfield. ${ }^{155}$ Similarly, and more recently, Saenz $v$. Roe involved a challenge by an out-of-state citizen to a durational residency requirement stopping her from claiming California welfare benefits. ${ }^{156}$ The case was litigated with a right-to-travel theory under the Privileges or Immunities Clause, but an originalist would probably find it more logical to situate the challenge under the Comity Clause. ${ }^{157}$ If the Comity Clause enforces a nondiscrimination principle without reference to any substantive content, no substantive principle stops the welfare benefits from counting as privileges and immunities as long as the court determines that welfare is important enough to count as a fundamental right. That result, and Toomer's conflict with Corfield, seem fairly inconsistent with the Constitution's federal structure. ${ }^{158}$ If, however, Anglo-American traditions and histories suggest that charitable entitlements are public benefits and not private rights, the nondiscrimination approach gets whatever determinacy it has by borrowing on moral principles latent in the authorities that determine which rights are fundamental and which are not. ${ }^{159}$

155. Toomer v. Witsell, 334 U.S. 385 (1948). The statute in Toomer allowed selected out-of-state fishermen to shrimp, on condition that they pay a license fee one hundred times greater than the fee for South Carolina fishermen and unload their cargo in South Carolina. See id. at 390-91 \& n.11.

156. 569 U.S. 489, 489-90 (1999).

157. U.S. CONST. art. IV, § 2, cl. 1.; Id.

158. See Paul v. Virginia, 75 U.S. (8 Wall.) 168, 181 (1868) (saying, of a claim by a corporation to the benefits another state provides to in-state corporations, that "[i]f [the Comity Clause] could be construed to secure to citizens of each State in other States the peculiar privileges conferred by their laws, an extra-territorial operation would be given to local legislation utterly destructive of the independence and the harmony of the States.”).

159. This issue is also relevant to whether originalists can transplant a very important noneconomic right from the Equal Protection Clause to the Privileges or Immunities Clause- the right to a public education declared in Brown v. Bd. of Educ., 


\section{The ORIGINAL Understanding OF PRIVILEGES OR IMMUNITIES}

The interpretations suggested in the previous Part are exploratory and suggestive, and they may be criticized in many ways. There are at least two significant general criticisms. The interpretations focus fairly closely on the literal meaning of privileges, immunities, and abridgments as terms of art. As Part I acknowledged, however, originalists may prefer to interpret legal text in light of original understandings or intentions. Separately, the previous Part's interpretation proceeds top-down. ${ }^{160}$ It assumes that Blackstone's usages of privileges, immunities, and abridgment are more or less accurate, it identifies important corroborating examples, and it interprets the text of the Fourteenth Amendment accordingly. In his contribution to this Symposium, however, Michael Rappaport issues a much-needed friendly warning to this approach: "The real world at any time is a messier place. While [the Founders and Reconstructionists] may have praised Locke, [they] also lived with various property regulations that were inconsistent with Lockean thought."161 Top-down methodology needs to be challenged by bottom-up verification.

To illustrate, the interpretation presented in the previous Part conflicts to a significant extent with how the terms privileges and immunities were understood in some lines of antebellum Comity Clause case law. The most revealing case is the 1812 New York decision Livingston $v$. Van Ingen. ${ }^{162}$ New York granted Livingston, a New York resident, an exclusive monopoly to operate a steamboat on a New York river for a limited term. Livingston sued Van Ingen and other out-of-state citizens

347 U.S. 483 (1954). The universal right to a public education is a positive entitlement from the state, not a negative liberty. If the fundamental rights covered by privileges and immunities have no necessary connection to negative rights of life, liberty, or property, and refer to any positive law rights that the local community considers important, it is more likely that this right counts as a constitutional privilege or immunity. See Steven G. Calabresi \& Sarah E. Agudo, Individual Rights Under State Constitutions When the Fourteenth Amendment Was Ratified in 1868: What Rights Are Deeply Rooted in American History and Tradition?, TEX. L. REV. (forthcoming 2008), available at http://papers.ssrn.com/sol3/ papers.cfm?abstract_id=1114940; Harrison, supra note 15, at 1462-63. If fundamental rights do require some direct connection to negative Lockean liberties, this right is much less likely to count as a privilege or immunity.

160. See supra notes 23-24 and accompanying text.

161. Michael B. Rappaport, Originalism and Regulatory Takings: Why the Fifth Amendment May Not Protect Against Regulatory Takings, but the Fourteenth Amendment May, 45 SAN Diego L. ReV. 729, 738 (2008).

162. 9 Johns. 507 (N.Y. 1812). 
for operating a competing steamboat in violation of his New York charter. Under fundamental rights principles, New York could within its police powers restrain free competition by granting a monopoly to operate a steamboat exclusively for a limited term - if it could be shown that the monopoly was necessary to encourage the growth of the steamboat industry and that the monopoly was reasonably appropriate to achieve that end. Similar principles informed state bridge-building ${ }^{163}$ and patent policy ${ }^{164}$ in the nineteenth century. If the steamboat industry did require encouragement by a monopoly, then under the Comity Clause, New York's monopoly did not deny but rather enforced a substantive proviso inherent in out-of-state citizens' privileges and immunities under the Clause. If not, then the monopoly did deny those citizens privileges or immunities to which they were entitled by the Comity Clause. ${ }^{165}$ While that determination would have been empirical, it is at least plausible to assume that the monopoly was not necessary to encourage steamboating and that the New York law did violate the Comity Clause.

That result strains the federal structure. A New York citizen could not challenge the steamboat monopoly under the pre-Civil War Constitution, but the Comity Clause would give out-of-state citizens immunity from the monopoly. Not every member of the New York Superior Court discussed Van Ingen's Comity Clause challenge in Livingston. But Chancellor Kent did, and used the nondiscrimination interpretation to foreclose this possibility: The Clause "means only that citizens of other states shall have equal rights with our own citizens, and not that they shall have different or greater rights.”"166

Kent's remarks provide some evidence that antebellum jurists understood privileges and immunities in the Comity Clause to leave states with wide latitude to specify the content of their property and commercial laws however they chose, and that the Comity Clause only required states to give out-of-state citizens access to the same protections as their own citizens enjoyed. Scholars have debated how well the nondiscrimination and fundamental rights views were represented in antebellum Comity Clause case law. ${ }^{167}$ The nondiscrimination view was

163. See, e.g., Charles River Bridge v. Warren Bridge, 36 U.S. (11 Peters) 420 (1837).

164. See Adam Mossoff, Who Cares What Thomas Jefferson Thought about Patents? Reevaluating the Patent "Privilege" in Historical Context, 92 CORNELL L. Rev. 953, 981-83 (2007).

165. U.S. ConST. art. IV, § 2, cl. 1.

166. Livingston, 9 Johns. at 577.

167. For three differing accounts, consider MALTZ, supra note 17, at 28-39 (finding the nondiscrimination approach to prevail early in the nineteenth century and the fundamental rights approach to become more popular as the slavery issue became more contentious mid-century); Harrison, supra note 15, at 1416-20 (nondiscrimination view 
well represented, ${ }^{168}$ but it is hard to determine precisely whether it or the fundamental rights approach prevailed. Except in cases like Livingston, differences between the two interpretations were "of little practical import" until the dispute over slavery erupted later. ${ }^{169}$

Even so, at a minimum, the nondiscrimination Comity Clause case law creates some evidence that constitutional privileges and immunities were not always understood by lawyers to follow Blackstonian fundamental rights principles wherever they led in constitutional law. This evidence could inform a textual analysis of the Privileges or Immunities Clause. Perhaps, when lawyers used privileges and immunities as terms of constitutional art, they ignored Blackstone's suggestions about natural law and understood privileges and immunities to refer to state positive law as it was. Alternatively - and in my opinion, more probably-this information could inform an original understanding interpretation of the Privileges or Immunities Clause. Even if likely literal dictionary meanings of privileges or immunities incorporated Blackstonian principles of fundamental rights, perhaps most lawyers and politicians as of 1866 would have revolted at following that literal meaning out of a concern for states' rights.

Although this essay cannot settle such issues, it can make a few general observations and highlight follow-up work that needs to be pursued. First, at a minimum, this essay shows that the positivist tendencies in nondiscrimination Comity Clause case law were not the only factor at work in antebellum, Civil War, and Reconstruction era understandings of privileges, immunities, and abridgments. A wide cross-section of otherwise disparate legal and political actors presumed that, when used in association with citizenship, privileges and immunities tracked Blackstonian theory about how the social compact required government to structure civil laws to secure basic natural rights.

That first insight leads to a second: It is possible that the Fourteenth Amendment's terms were reasonably read by the reasonable intended audience-or were generally understood according to the dominant understanding as of ratification - to codify the substantive natural rights tendencies of privileges and immunities more than earlier nondiscrimination

dominates); David R. Upham, Note, Corfield v. Coryell and the Privileges and Immunities of American Citizenship, 83 TEx. L. REV. 1483, 1498-1510 (2005) (finding three different lines of Comity Clause cases, with the fundamental rights line prevailing).

168. See, e.g., KENT, supra note 37, at 71.

169. MALTZ, supra note 17 , at 34. 
Comity Clause case law had. The materials interpreted in this essay reinforce an insight of Earl Maltz about the selective use of Comity Clause case law during and after the Civil War. When Livingston was decided in 1812,

the idea of a state government failing to provide its own citizens generally with the rights discussed in Corfield was almost unthinkable. . . . By contrast, in the struggle over the status of slavery and the rights of free blacks, the choice between Comity Clause theories at times became critical. ${ }^{170}$

On one hand, Livingston gets some priority over Corfield because it was decided a decade closer to the ratification of the Constitution than Corfield was. But for the purposes of understanding the Fourteenth Amendment, Corfield might ultimately get higher priority. Corfield speaks of privileges and immunities of citizenship with explicit reference to the same higher law rights that informed the Declaration of Independence and inspired the struggle against slavery. Once the slavery issue became important, those references might have mattered more to jurists and statesmen involved with the slavery struggle. It is revealing that legislators like Senators Trumbull and Howard referred to Corfield and not Livingston as the best understanding of privileges and immunities of citizenship. ${ }^{171}$

Finally, and most important, the discussion presented here underscores that antebellum Comity Clause case law is not the only evidence of particular legal or political practices relevant to the original meaning or understanding of privileges and immunities as terms of art in the Fourteenth Amendment. Blackstone's treatment of privileges, immunities, and abridgment has sweeping implications. Blackstone uses privileges and immunities, after all, as a metaphor for the civil rights individuals should enjoy in a society with a free and republican government. Blackstone could speak of the legal rights of the unborn, the affirmative defenses against homicide, prohibitions against torture, habeas corpus, or eminent domain as specific examples of privileges or immunities securing absolute moral rights. ${ }^{172}$ Each of these examples, however, was just an example. As terms of art for the social compact, privileges and immunities include any civil laws instituted to secure and specify the natural rights of life, liberty, or property, consistent with AngloAmerican practice, for the peculiar benefit of a free and republican citizenry informed by Anglo-American law, religion, and tradition. To nail down the meaning of privileges and immunities as used in the

170. Id.

171. See supra notes 79 and 96 and accompanying text.

172. See 1 BlaCKSTONE, supra note 18 , at *126 (unborn), *126-27 (homicide), *129-30 (torture), *130-32 (habeas corpus), *14-35 (eminent domain). 
Fourteenth Amendment, one would need to survey how the terms were used in all contexts in which Blackstone's usage makes them relevant.

For example, one might reasonably be skeptical that nineteenthcentury patent policy has anything to say about privileges and immunities as constitutional terms of art. Not necessarily. Patents were called privileges in the nineteenth century. Most contemporary patent scholars jump to the anachronistic conclusion that patents were therefore regarded as "governmentally conferred rights" assigned to inventors "as the beneficiaries of a government license and [only] as . . . sufficient to encourage innovation."173 That conventional wisdom notwithstanding, patents fit Blackstone's conception of property privileges perfectly. While "[t]he original of private property is probably founded in nature," Blackstone suggested, "the modifications under which we at present find it . . . are entirely derived from society." ${ }^{174}$ A patent is a civil law securing to and specifying for an inventor his absolute right of property. It defines the legal metes and bounds around the invention and the term of years in which the owner may extract his natural right, a reasonable compensation for the fruits of his labor. In other words, a patent is therefore a Blackstonian privilege. As Adam Mossoff has shown, when nineteenthcentury American jurists referred to patents as privileges, they followed this sense-and the natural rights principles inherent in privilege gave patent doctrine substantive content that followed from Lockean and Blackstonian principles of productive labor. ${ }^{175}$ Mossoff's findings confirm that Corfield's treatment of privileges and immunities accord with one important area of economic regulation more than Livingston's.

If enough other areas of law provide similar confirmation, the confirmation would provide strong evidence explaining why Reconstruction era legislators regarded Corfield as a more accurate exposition of privileges and immunities than Livingston. Of course, that is a huge undertaking. State constitutions and property and commercial regulations might refer to property or commercial rights as privileges or immunities in ways as revealing as patent law. Since privileges and immunities refer to rights essential to citizenship, state and federal immigration and naturalization

173. Mark A. Lemley \& Philip J. Weiser, Should Property or Liability Rules Govern Information?, 85 TEX. L. REV. 783, 783 (2007).

174. 1 BLACKSTONE, supra note 18 , at $* 134$.

175. See Mossoff, supra note 164, at 990-92. 
laws may shed relevant light. ${ }^{176}$ For the same reason, United States treaties might also be relevant, if they promised that the United States would give the subjects of foreign governments the same protections as the privileges or immunities to which U.S. citizens were entitled. ${ }^{177}$ It is no answer to say that some lines of Comity Clause case law deserve pride of place over other evidence because the Comity Clause is a constitutional doctrine. Each of these sources needs to be considered not based on its hierarchical status but by the extent to which it sheds meaningful light on the meaning of-or understanding behind-privileges, immunities, citizens, and abridging as terms of art in the Fourteenth Amendment.

Of course, these inquiries are simply suggestive. For example, assume it could be shown that the drafters and ratifiers of the Fourteenth Amendment chose the terms privileges and immunities to pick up the terms' higher law associations from Blackstone and Corfield. In an original-understanding analysis, that showing might prove that the drafters and ratifiers understood the Fourteenth Amendment to disrupt federalism only as necessary to rectify black-white race relations in the Reconstruction South. In other words, even though the Privileges or Immunities Clause codified higher law principles, perhaps it was generally understood that such principles would not be used to give federal legislators and courts the power to negate state zoning laws, licensing schemes, and other nondiscriminatory property or commercial regulations that interfere with classical liberal government theory. This and many other objections would need to be considered. My point here is simply that scholarship has only begun to scratch the surface of a complicated historical reclamation project.

\section{CONCLUSION}

Blackstone's Commentaries portray privileges and immunities associated with free government in a focused manner. In Blackstone's portrait, privileges and immunities refer to civil laws, securing absolute natural rights of life, liberty, and property, to the individuals who consent to join a free political community. Important public documents, treatises, and statements, from the United States' colonial period, founding, and Reconstruction periods, all assume an understanding substantially similar to Blackstone's, as adapted to the context of a country organized explicitly

176. See generally Rogers M. SMith, CiVIC IdEALs: CONFLiCting Visions OF CiTIZENSHIP IN U.S. HISTORY (1997) (examining the evolution of rights in America as a result of political, legal, and historical change).

177. See AMAR, supra note 19, at 167-69. 
around the republican principles articulated in the Declaration of Independence.

With qualifications, Blackstone's portrait provides some additional evidence that Professor Siegan was on the right track in his scholarship on the Privileges or Immunities Clause. Among other reasons, Blackstone's portrait makes extremely explicit the connection between privileges, immunities, and absolute and fundamental natural rights. Blackstone provides historical and theoretical context in which Corfield v. Coryell makes far more sense as the leading American constitutional pronouncement on privileges and immunities. Blackstone also provides important confirming evidence that abridging, as used in the Privileges or Immunities Clause, accords more with the fundamental rights reading than with alternative interpretations.

Of course, Blackstone's Commentaries are hardly dispositive by themselves. The Fourteenth Amendment was ratified eighty years after the Commentaries - in a different country, in different historical circumstances, after a lot of messy and inconsistent practices corroborating or undercutting Blackstone's portrait. At the same time, Blackstone's Commentaries provide a clear window on how pre-Civil War American statesmen and lawyers understood privileges and immunities as terms of law and political theory. That window should in turn help originalists determine more precisely how privileges and immunities were understood in context as terms of art for the civil rights citizens were entitled to enjoy in a republican political community. 
